\title{
Keloid Scars: An Updated Review of Combination Therapies
}

\author{
Nicholas J. Thornton ${ }^{1}$, Benjamin A. Garcia ${ }^{1}$, Paige Hoyer ${ }^{1}$, Michael G. Wilkerson ${ }^{1}$ \\ 1. Dermatology, University of Texas Medical Branch, Galveston, USA
}

Corresponding author: Nicholas J. Thornton, njthornt@utmb.edu

\begin{abstract}
Keloid scars are a common yet poorly understood complication of wound healing that can cause a diminished quality of life. Currently, there is little agreement amongst the medical community regarding the best treatment modality for keloids. For this reason, we have created an updated review of the most successful combination therapies for keloid scars and compared their efficacy based on rates of recurrence following treatment. Additionally, these combination therapies have been compared with intralesional triamcinolone acetonide corticosteroid (TAC), which is considered the mainstay monotherapy for keloids. All combination therapies included in our review were shown to produce superior outcomes than TAC monotherapy. We have also found that certain combination therapies are known to produce superior results when used in specific anatomic locations. Intralesional TAC plus intralesional cryotherapy appeared to have the most promising results for non-auricular keloids, and the authors suggest considering this as a first-line treatment. Additionally, the use of surgical excision plus compression therapy achieved superior results for auricular keloids and should be considered first-line for keloids in these locations.
\end{abstract}

Review began 01/20/2021 Review ended 01/26/2021 Published 01/30/2021

(c) Copyright 2021 Thornton et al. This is an open access article distributed under the terms of the Creative Commons Attribution License CC-BY 4.0., which permits unrestricted use, distribution, and reproduction in any medium, provided the original author and source are credited.
Categories: Dermatology

Keywords: keloid, keloid scar, keloid treatment, keloid therapy, combination therapy for keloids, combination versus monotherapy for keloids, combination therapy for keloid scars, treating keloids, combination treatment for keloids

\section{Introduction And Background}

Keloid scars are a common yet poorly understood complication of wound healing that can cause a diminished quality of life. The pathogenesis is thought to involve aberrant collagen deposition extending beyond the original wound margins. Many factors have been correlated with a predisposition to keloid formation including specific HLA subtypes, blood type aII, Fitzpatrick skin types V-VI, and age from 10 to 30 years old [1]. Aspects of initial wound management have also been correlated with the formation of keloid scars including delayed debridement, heavy inflammation, and excessive wound tension [1]. Currently, there is little agreement amongst the medical community regarding the best treatment modality for keloids. Recent studies suggest that a multimodal approach is necessary to achieve successful resolution and to decrease rates of recurrence [2-4]. The goal of this review is to compare the most successful current keloid therapies in order to assist physicians in selecting the most appropriate regimen for their patients.

\section{Methods}

This review utilized the Medline database via the PubMed search engine to identify reviews published from 2010 to 2020 examining current treatments for keloid scars. Keywords used were "keloid", "keloid treatment", "keloid review", "keloid therapy". Articles that failed to provide recurrence rates, or a minimum three-month follow up period were excluded. Over 40 articles were identified and nine were selected for inclusion.

\section{Review \\ Results}

Due to the subjective nature of comparing aesthetic results, recurrence rate was chosen as the primary metric for comparison. Combination therapies including surgical excision were categorized as "surgical combination therapy". Combination therapies not involving surgical intervention were categorized as "medical combination therapy".

Mainstay Monotherapy

Triamcinolone Acetonide Corticosteroid (TAC) Injection. For years TAC injection has been utilized to treat keloid scars. It is injected in concentrations of 10 to $40 \mathrm{mg} / \mathrm{mL}$ administered intralesionally at no less than four- to six-week intervals to avoid adrenal suppression. It has been touted by several studies as the mainstay monotherapy for keloids [1-4]. Its ability to treat keloids is hypothesized to be due to suppression of inflammatory pathways, suppression of fibroblast development and collagen production, and promotion of collagen degradation [1]. TAC is widely available, relatively inexpensive, and easy to administer. When 
utilized alone as monotherapy, mean recurrence rates are 33\% and 50\% at one- and five-year follow-up, respectively. The most common side effects of TAC injection are hypopigmentation and dermal atrophy [5].

\section{Surgical Combination Therapies}

Surgical Excision + TAC. Surgical excision in combination with TAC injections has shown a substantial reduction in recurrence of auricular keloids when compared with either therapy used alone. This therapy is generally accomplished by performing complete excision with either a low-tension primary closure or healing by second intention, plus same-day TAC injections with concentrations ranging from 5-10 $\mathrm{mg} / \mathrm{mL}$. Patients then return for monthly TAC injection over the course of four to six months postoperatively. Excision + TAC is shown to have a mean recurrence rate of $15.4 \%$ with a follow-up of 12 to 35 months. Primary side effects are hypopigmentation and dermal atrophy [6].

Surgical Excision + Radiation. Surgical excision with adjuvant radiation therapy performed within 24 hours postoperatively with a total dose no less than 12 Gray has been associated with a mean recurrence rate of $23 \%$ at 14 months follow up. This therapy is comparable to surgical excision and TAC combination therapy in terms of efficacy. It has been suggested that surgical excision plus radiation is an acceptable salvage therapy following a failed response to excision plus TAC [7]. Radiation should not be utilized in children, pregnant women, or those with underlying malignancy. The most common side effects are hyperpigmentation and hypopigmentation [4]. The theoretical risk of malignancy as a side effect from radiation therapy has been discussed ever since the implementation of this treatment, however, a 2019 comprehensive review of radiation therapy for keloids suggests that this risk remains negligible [8]. The current consensus regarding radiation therapy for keloids is that it is safe and effective for treating keloid scars with minimal long-term risk.

Surgical Excision + Pressure Therapy. Surgical excision followed by pressure therapy is an ideal choice of treatment for keloids located on the ear as this anatomic location is particularly amenable to the implementation of pressure fitting devices such as pressure earrings. This combination is utilized by instructing patients to wear pressure devices over the excised area where the keloid was originally located. The devices often employ the use of magnets to achieve effective compression of the healing area. Pressure therapy is cost-effective and simple but is much less beneficial in anatomic locations outside of the ear. With regards to auricular keloids specifically, this combination therapy is associated with a $6.7 \%-10.6 \%$ recurrence rate at 18-month follow-up period. Because of the exceptional efficacy and low recurrence rate, this combination therapy should always be considered for first-line treatment of keloid scars on the ear [9].

Surgical Excision + Cryotherapy. Surgical excision followed by the use of topical cryotherapy has also shown acceptable results for the treatment of auricular keloids. Excision is followed immediately postoperatively by topical cryotherapy using cryoprobes (direct contact method) to attain an impedance value of $1000 \mathrm{~K} \Omega$ as measured by an impedance meter. Achieving this value generally requires a single freeze-thaw cycle of about 30 seconds [10]. Different size cryo-probes can be selected based on size of the lesion in order to provide an even distribution of contact, and thus even freezing, to the entire keloid. Recurrence rates have been demonstrated as $15 \%$ recurrence with a median follow-up of 43 months. The primary side effect following treatment was hypopigmentation, especially in patients with skin of color [10]. Larger keloids located outside of the ear may not benefit as greatly from this combination due to the difficulty in achieving effective freezing on larger anatomic areas.

Surgical Excision + Mitomycin C (MC). Surgical excision followed by application of topical MC has recently been shown to produce acceptable results as a combination therapy for the treatment of keloids in various anatomic locations. Mitomycin $\mathrm{C}$ is a chemotherapeutic agent that is capable of decreasing fibroblast production and cell division by inhibiting transcription of DNA to RNA. It accomplishes this by creating DNA crosslinks [2]. After excision, gauze soaked with MC at a dose of $1 \mathrm{mg} / \mathrm{ml}$ is generally applied for 3-5 minutes postoperatively and again at three weeks post-op. Keloid recurrence rates after surgical excision plus MC combination therapy have been shown to average $16.5 \%$ with a mean follow-up period of sixmonth duration [11]. There is potential for dose-dependent adverse effects with MC and it should be carefully dosed at $1 \mathrm{mg} / \mathrm{ml}$ to avoid these potential complications [11]. Additionally, MC should never be used in pregnant patients due to the potential for harm to the developing fetus [12].

Surgical Excision + Imiquimod. Surgical excision followed by application of topical Imiquimod has been shown to have similar but slightly inferior results when compared to excision and MC combination therapy. Imiquimod is a potent immune modulator and functions by stimulating an immune response via synergistic activation of several distinct pathways [13]. Imiquimod stimulates toll-like receptors 7 and 8 leading to activation of nuclear factor-kappa B [13]. Imiquimod also stimulates the expression of tissue necrotic factoralpha, alpha and gamma interferon, and interleukins 1,6,8, and 12 [13]. Excision plus Imiquimod combination treatment is performed by applying $5 \%$ Imiquimod cream to the surgical site nightly for six to eight weeks post excision. Results show a mean recurrence rate of $24.7 \%$ with an average follow-up period of six months [11]. 
TAC + Laser Therapy. Recently, the use of lasers has shown promising results throughout the field of dermatology. Similarly, combination treatment of keloids with lasers has also shown favorable outcomes. CO2 lasers are thought to work synergistically with TAC by decreasing fibroblast activity thus minimizing production of collagen [14]. The CO2 laser emits light at a wavelength of $10,600 \mathrm{~nm}$ that is then absorbed by water. This results in tissue vaporization and effectively creates individual rows of vaporized tissue surrounded by normal skin that are known as Microthermal Zones or MTZ's [15]. These MTZ's assist in tissue regeneration by eliciting a robust wound healing response [15]. Studies have analyzed the results of CO2 Laser ablation of keloids followed by monthly intralesional TAC treatment for up to six months following laser procedure. Results have shown a mean recurrence of $15.4 \%$ with a mean follow-up of six months. Primary side effects from CO2 laser ablation are pain and hypopigmentation [16].

TAC + 5-Fluororacil (5-FU). The use of intralesional 5-FU as a monotherapy to replace TAC has been heavily examined in the recent literature, but most data fails to show superiority to TAC monotherapy [17]. However, TAC+5-FU has been demonstrated to alleviate many of the deleterious side effects associated with TAC monotherapy while retaining slightly improved or similar overall outcomes. Recurrence rates have not been well elucidated for this combination therapy and have ranged between $0 \%$ and $47 \%$ in various studies [17]. Despite the lack of uniform evidence demonstrating low recurrence, this therapy deems itself worthy of consideration due to its superiority over either of its two ingredients used alone and ease of administration [17]. However, patients may require anesthetic prior to 5-FU injections to improve tolerability.

TAC + Intralesional Cryotherapy. TAC has also been combined with intralesional cryotherapy to achieve acceptable results. Weshahy and Abdel Hay et al. demonstrated the effectiveness of intralesional cryotherapy followed by TAC injections over the course of six months. The intralesional cryotherapy is administered by inserting cryo needles at or below the base of the lesion and allowing freezing of the blood supply of the keloid to occur. TAC is subsequently injected into the lesion over the following several months. Results of this study found only a $12 \%$ recurrence at six-month follow-up period [18].

\section{Miscellaneous Treatments}

A recent meta-analysis by Ellis et al. chose to compare dual therapy to triple therapy for treating keloids and found that there was no overall statistical difference between dual and triple therapy [19]. However, when dual therapy consisting of excision plus radiation was compared to excision, radiation, and another treatment (either hyperbaric oxygen or platelet-rich plasma therapy), a statistical difference was observed [19]. Hyperbaric oxygen and platelet-rich plasma therapy for keloids is not sufficiently studied, but both options have shown promise when used in combination with at least two additional treatment modalities $[20,21]$.

It is worth noting that Interferon therapy has been utilized following surgical excision with acceptable outcomes but was not included in this study due to being published outside of the inclusion timeline. TAC and all included combination therapies are compared as seen in Table 1. 


\section{Cureus}

\begin{tabular}{|c|c|c|c|c|c|c|c|}
\hline Type & Treatment & $\begin{array}{l}\text { Average } \\
\text { recurrence } \\
\text { rate }(\%)\end{array}$ & $\begin{array}{l}\text { Average } \\
\text { follow- } \\
\text { up } \\
\text { (months) }\end{array}$ & Design & Primary results & Benefits & Authors \\
\hline Monotherapy & TAC & $33 \%$ & $\begin{array}{l}12 \\
\text { months }\end{array}$ & Review & $\begin{array}{l}\text { TAC injection shows } 50- \\
100 \% \text { regression after } \\
\text { treatment but has high } \\
\text { recurrence rates }\end{array}$ & $\begin{array}{l}\text { Inexpensive/Easy to } \\
\text { administer/Relatively safe }\end{array}$ & $\begin{array}{l}\text { Morelli } \\
\text { Coppola et } \\
\text { al. [5] }\end{array}$ \\
\hline \multirow[t]{4}{*}{$\begin{array}{l}\text { Surgical } \\
\text { combination } \\
\text { therapy }\end{array}$} & $\begin{array}{l}\text { Surgical } \\
\text { Excision + } \\
\text { Radiation }\end{array}$ & $23 \%$ & $\begin{array}{l}14 \\
\text { months }\end{array}$ & Review & $\begin{array}{l}\text { Significant reduction in } \\
\text { recurrence when } \\
\text { compared to excision or } \\
\text { radiation monotherapy }\end{array}$ & $\begin{array}{l}\text { Effective and quick symptom } \\
\text { relief/Low recurrence/Fewer } \\
\text { treatment sessions required }\end{array}$ & $\begin{array}{l}\text { Mankowski } \\
\text { et al. [4] }\end{array}$ \\
\hline & $\begin{array}{l}\text { Surgical } \\
\text { Excision + } \\
\text { TAC }\end{array}$ & $15.4 \%$ & $\begin{array}{l}12-35 \\
\text { months }\end{array}$ & Review & $\begin{array}{l}\text { Significant reduction in } \\
\text { recurrence compared to } \\
\text { excision or TAC } \\
\text { monotherapy }\end{array}$ & $\begin{array}{l}\text { Ideal for auricular } \\
\text { keloids/Effective and quick } \\
\text { symptom relief/Low recurrence }\end{array}$ & $\begin{array}{l}\text { Shin et al. } \\
\text { [6] }\end{array}$ \\
\hline & $\begin{array}{l}\text { Surgical } \\
\text { Excision }+ \\
\text { Pressure } \\
\text { Therapy }\end{array}$ & $10.6 \%$ & $\begin{array}{l}18 \\
\text { months }\end{array}$ & Prospective & $\begin{array}{l}\text { Excellent results } \\
\text { obtained for patients } \\
\text { with auricular keloids }\end{array}$ & $\begin{array}{l}\text { Ideal first-line treatment for } \\
\text { auricular keloids/Pressure } \\
\text { therapy is a minimally invasive, } \\
\text { inexpensive adjunct/Lower } \\
\text { recurrence rates than Excision + } \\
\text { TAC, or Excision + Cryotherapy } \\
\text { for auricular keloids }\end{array}$ & $\begin{array}{l}\text { Park et al. } \\
\text { [9] }\end{array}$ \\
\hline & $\begin{array}{l}\text { Surgical } \\
\text { Excision + } \\
\text { Cryotherapy }\end{array}$ & $15 \%$ & $\begin{array}{l}43 \\
\text { months }\end{array}$ & Retrospective & $\begin{array}{l}\text { Excellent results } \\
\text { obtained for patients } \\
\text { with auricular keloids }\end{array}$ & Ideal for large auricular keloids & $\begin{array}{l}\text { Litrowski } \\
\text { et al. [10] }\end{array}$ \\
\hline \multirow{4}{*}{$\begin{array}{l}\text { Medical } \\
\text { combination } \\
\text { therapy }\end{array}$} & $\begin{array}{l}\text { Surgical } \\
\text { Excision }+ \\
\text { Mitomycin } \\
\text { C }\end{array}$ & $16.5 \%$ & $\begin{array}{l}6 \\
\text { months }\end{array}$ & Review & $\begin{array}{l}\text { Similar efficacy to } \\
\text { excision + TAC but with } \\
\text { potential dose- } \\
\text { dependent adverse } \\
\text { effects }\end{array}$ & $\begin{array}{l}\text { Less efficacious when } \\
\text { compared to excision }+ \\
\text { TAC/May be useful if TAC not } \\
\text { available }\end{array}$ & $\begin{array}{l}\text { Shin et al. } \\
\text { [11] }\end{array}$ \\
\hline & $\begin{array}{l}\text { Surgical } \\
\text { Excision + } \\
\text { Imiquimod }\end{array}$ & $24.7 \%$ & $\begin{array}{l}6 \\
\text { months }\end{array}$ & Review & $\begin{array}{l}\text { Higher recurrence } \\
\text { compared to excision + } \\
\text { MC but with less risk of } \\
\text { adverse side effect }\end{array}$ & $\begin{array}{l}\text { Less efficacious when } \\
\text { compared to excision }+ \\
\text { TAC/May be useful if TAC not } \\
\text { available }\end{array}$ & $\begin{array}{l}\text { Shin et al. } \\
\text { [11] }\end{array}$ \\
\hline & $\begin{array}{l}\text { TAC + } \\
\text { Laser } \\
\text { Therapy }\end{array}$ & $15 \%$ & $\begin{array}{l}6 \\
\text { months }\end{array}$ & Prospective & $\begin{array}{l}\text { Superior results than } \\
\text { laser or TAC } \\
\text { monotherapy }\end{array}$ & Ideal for large difficult keloids & $\begin{array}{l}\text { Garg et al. } \\
\text { [16] }\end{array}$ \\
\hline & $\begin{array}{l}\text { TAC + 5- } \\
\text { Fluoruracil }\end{array}$ & $17.5 \%$ & $\begin{array}{l}3 \\
\text { months }\end{array}$ & $\mathrm{RCT}$ & $\begin{array}{l}\text { Superior results and less } \\
\text { recurrence compared to } \\
\text { TAC monotherapy }\end{array}$ & $\begin{array}{l}\text { Decreased side effects } \\
\text { compared to TAC or } 5 \text {-FU } \\
\text { monotherapy }\end{array}$ & $\begin{array}{l}\text { Khalid et } \\
\text { al. [17] }\end{array}$ \\
\hline & $\begin{array}{l}\text { TAC + } \\
\text { Intralesional } \\
\text { Cryotherapy }\end{array}$ & $12 \%$ & $\begin{array}{l}6 \\
\text { months }\end{array}$ & Pilot study & $\begin{array}{l}\text { Intralesional cryotherapy } \\
\text { performed prior to TAC } \\
\text { injection showed } \\
\text { superior results, } \\
\text { decreased side effects, } \\
\text { and a lower recurrence } \\
\text { rate than TAC } \\
\text { monotherapy }\end{array}$ & $\begin{array}{l}\text { Cost-effective/Useful for most } \\
\text { anatomic locations/Widely } \\
\text { available }\end{array}$ & $\begin{array}{l}\text { Weshahy } \\
\text { et al. [18] }\end{array}$ \\
\hline
\end{tabular}

\section{TABLE 1: Comparison of TAC and combination therapies.}

This table is inspired by the table created by Ekstein et al. and displays the most effective combination therapies defined as either surgical or medical combination therapy as well as the mainstay monotherapy [2]. Results are compared via recurrence rates and special considerations for each technique are included. TAC: triamcinolone acetonide corticosteroid. 


\section{Discussion}

TAC injections used as monotherapy for keloids are associated with increased rates of recurrence and greater side effect profile when compared to combination therapy. Even studies that have found no significant difference in resolution or recurrence between TAC monotherapy versus TAC combination therapy have reported a reduction in deleterious side effects when TAC is utilized with additional therapy such as 5-FU [5]. These findings indicate that superior outcomes can be achieved when employing a combined therapy for keloids. Each combination method has unique risks and benefits that must be considered when selecting the most appropriate regimen for the patient.

Patient preferences should be addressed when developing a personalized treatment regimen capable of achieving desired outcomes. Not all patients experience the same keloid symptoms and while some may primarily wish to alleviate pain and pruritus, others are simply concerned with aesthetics. Patients with particularly debilitating symptoms may desire quick resolution despite the invasive nature of procedures. Patients with a history of recurrence or prior history of keloids might benefit from more aggressive initial therapy as well. In contrast, patients who do not experience active side effects and wish to remove keloids solely for cosmetic reasons may prefer a conservative approach that can be performed over the course of several months to minimize discomfort. When treating keloids, a thorough discussion between patient and provider should take place in order to select the combination therapy that is most likely to achieve the best results.

\section{Conclusions}

Intralesional TAC plus intralesional cryotherapy appeared to have the most promising results for nonauricular keloids, and the authors suggest considering this as first-line treatment. Additionally, the use of surgical excision plus compression therapy achieved superior results for auricular keloids and should be considered first-line for keloids in these locations. Comparison of the existing literature on keloid treatment is challenging due to lack of standardization across studies. Many recent studies have variable follow up periods, differences in provider techniques, and widely varying keloid characteristics. This review focused on combination therapy with only two treatment modalities, however, future research may be warranted to assess the benefit of using three or more types of treatment for keloids. Future research with standardization among factors such as keloid characteristics and follow up intervals would be beneficial for the medical community. As our understanding of the pathophysiology of keloid scars continues to improve, we will gain a better appreciation for which characteristics of patients are best suited for each distinct treatment protocol. In the future, effective monotherapy for keloids may be discovered. Until then, current data suggest that a combined approach will yield the most successful results and best patient outcomes.

\section{Additional Information}

\section{Disclosures}

Conflicts of interest: In compliance with the ICMJE uniform disclosure form, all authors declare the following: Payment/services info: All authors have declared that no financial support was received from any organization for the submitted work. Financial relationships: All authors have declared that they have no financial relationships at present or within the previous three years with any organizations that might have an interest in the submitted work. Other relationships: All authors have declared that there are no other relationships or activities that could appear to have influenced the submitted work.

\section{References}

1. Limandjaja GC, Niessen FB, Scheper RJ, Gibbs S: The keloid disorder: heterogeneity, histopathology, mechanisms and models. Front Cell Dev Biol. 2020,

2. Ekstein SF, Wyles SP, Moran SL, Meves A: Keloids: a review of therapeutic management . Int J Dermatol. 2020, 10.1111/ijd.15159

3. Limmer EE, Glass DA: A review of current keloid management: mainstay monotherapies and emerging approaches. Dermatol Ther. 2020, 10:931-948. 10.1007/s13555-020-00427-2

4. Mankowski P, Kanevsky J, Tomlinson J, et al.: Optimizing radiotherapy for keloids: a meta-analysis systematic review comparing recurrence rates between different radiation modalities. Ann Plastic Surge. 2017, 78:403-411. 10.1097/SAP.0000000000000989

5. Morelli Coppola M, Salzillo R, Segreto F, et al.: Triamcinolone acetonide intralesional injection for the treatment of keloid scars: patient selection and perspectives. Clin Cosmetic Investigational Dermatol. 2018, 11:387-396. 10.2147/CCID.S133672

6. Shin JY, Lee JW, Roh SG, et al.: A comparison of the effectiveness of triamcinolone and radiation therapy for ear keloids after surgical excision: a systematic review and meta-analysis. Plastic Reconstruct Surg. 2016, 137:1718-1725. 10.1097/PRS.0000000000002165

7. Al-Attar A, Mess S, Thomassen JM, et al.: Keloid pathogenesis and treatment. Plastic Reconstruct Surg. 1963, 117:286-300.

8. Xu J, Yang E, Yu NZ, et al.: Radiation therapy in keloids treatment: history, strategy, effectiveness, and complication. Chin Med J. 2017, 130:1715-1721. 10.4103/0366-6999.209896

9. Park TH, Seo SW, Kim JK. et al.: Outcomes of surgical excision with pressure therapy using magnets and identification of risk factors for recurrent keloids. Plastic Reconstruct Surg. 2011, 128:431-439. 10.1097/PRS.0b013e31821e7006 
10. Litrowski N, Boullie MC, Dehesdin D, et al.: Treatment of earlobe keloids by surgical excision and cryosurgery. J Eur Acad Dermatol Venereol. 2014, 28:1324-1331. 10.1111/jdv.12282

11. Shin JY, Yun SK, Roh SG, et al.: Efficacy of 2 representative topical agents to prevent keloid recurrence after surgical excision. J Oral Maxillofacial Surg. 2017, 75:401.e1-401.e6. 10.1016/j.joms.2016.10.009

12. FDA Approves First Therapy for Treatment of Low-Grade Upper Tract Urothelial Cancer. U.S. Food and Drug Administration (FDA) (Press Release). (2020). Accessed: 15 April: https://www.fda.gov/news-events/pressannouncements/fda-approves-first-therapy-treatment-low-grade-upper-tract-urothe....

13. Schon MP, Schon M: Imiquimod mode of action. Br J Dermatol. 2007, 157:8-13.

14. El-Zawahry BM, Sobhi RM, Bassiouny DA, et al.: Ablative CO 2 fractional resurfacing in treatment of thermal burn scars: an open-label controlled clinical and histopathological study. J Cosmetic Dermatol. 2015, 14:324-331. 10.1111/jocd.12163

15. Kraeva E, Ho D, Jagdeo J: Successful treatment of keloid with fractionated carbon dioxide (CO2) laser and laser-assisted drug delivery of triamcinolone acetonide ointment in an African-American man. J Drugs Dermatol. 2017, 16:925-927.

16. Garg SA, Sao PP, Khopkar US: Effect of carbon dioxide laser ablation followed by intralesional steroids on keloids. J Cutaneous Aesthetic Surg. 2011, 4:2-6. 10.4103/0974-2077.79176

17. Khalid FA, Mehrose MY, Saleem M, et al.: Comparison of efficacy and safety of intralesional triamcinolone and combination of triamcinolone with 5-fluorouracil in the treatment of keloids and hypertrophic scars: randomised control trial. Burns. 2019, 45:69-75. 10.1016/j.burns.2018.08.011

18. Weshahy AH, Abdel Hay R: Intralesional cryosurgery and intralesional steroid injection: a good combination therapy for treatment of keloids and hypertrophic scars. Dermatologic Therapy. 2012, 25:273276. 10.1111/j.1529-8019.2012.01456.x

19. Ellis M, Jones LR, Siddiqui F, et al.: The efficacy of surgical excision plus adjuvant multimodal therapies in the treatment of keloids: a systematic review and meta-analysis. Dermatologic Surg. 2020, 46:1054-1059. 10.1097/DSS.0000000000002362

20. Jones ME, Hardy C, Ridgway J: Keloid management: a retrospective case review on a new approach using surgical excision, platelet-rich plasma, and in-office superficial photon x-ray radiation therapy. Adv Skin Wound Care. 2016, 29:303-307. 10.1097/01.ASW.0000482993.64811.74

21. Song K, Liu S, Zhang M, et al.: Hyperbaric oxygen therapy improves the effect of keloid surgery and radiotherapy by reducing the recurrence rate. J Zhejiang Univ Sci B. 2018, 19:853-862.

10.1631/jzus.B1800132 